\title{
Analisis semiotika Roland Barthes mengenai pseudobulbar affect dalam film Joker
}

\author{
Muhammad Alif Agisa ${ }^{1}$, Fardiah Oktariani Lubis ${ }^{2}$, Ana Fitriana Poerana ${ }^{3}$ \\ ${ }^{1,2,3}$ Universitas Singaperbangsa Karawang, Karawang, Indonesia
}

\begin{abstract}
ABSTRAK
Sebuah film pastilah mempunyai pesan-pesan serta makna yang akan disampaikan kepada penotonnya. Pesan dan makna tersebut tidak selalu terlihat secara langsung, dan berbeda penafsirannya. Tujuan dari penelitian ini adalah mencari makna denotasi, konotasi, dan mitos dari pseudobulbar affect (PBA) tokoh Arthur Fleck dalam film Joker. Film Joker mengisahkan seorang komedian bernama Arthur Fleck yang mengidap penyakit pseudobulbar affect (PBA), yaitu gangguan neurologis yang menyebabkan penderita kehilangan kontrol emosi secara sementara. Arthur Fleck adalah seorang pria dewasa dengan berbagai masalah yang menimpanya, sehingga membuat Arthur menjadi penjahat yang bernama Joker. Analisis semiotika Roland Barthes adalah teknik analisis yang peneliti gunakan. Peneliti menggunakan rekaman video film Joker sebagai sumber data, kemudian dilanjutkan dengan pemilihan beberapa adegan yang berkaitan dengan pseudobulbar affect. Data tersebut kemudian dianalisis menggunakan semiotika Roland Barthes untuk mencari makna denotasi, konotasi, serta mitos yang ada pada adegan tersebut. Diperoleh hasil bahwa makna denotasi dalam film ini adalah mengisahkan seorang komedian bernama Arthur Fleck yang mengidap penyakit pseudobulbar affect (PBA) dengan berbagai masalah yang menimpanya sehingga membuat ia menjadi seorang penjahat yang bernama Joker. Makna konotasinya adalah tertawa Arthur Fleck yang tidak dapat ia kendalikan, diartikan oleh orang-orang sekitarnya sebagai cemoohan, gangguan, hingga ancaman. Mitosnya adalah stigma masyarakat yang negatif terhadap Orang Dengan Gangguan Jiwa (ODGJ), membuat ODGJ kesulitan untuk berinteraksi secara sosial, dijauhi, dan diolok-olok.
\end{abstract}

Kata-kata Kunci: Semiotika; Roland Barthes; pseudobulbar affect; film; Joker

\section{Roland Barthes'semiotic analysis of pseudobulbar affect in the Joker Movie}

\begin{abstract}
The movie has meanings and messages to be conveyed to the audience. The messages and meanings are not always directly visible and differ in interpretation. This research was to determine the meaning of the denotation, connotation, and myths of the pseudobulbar affect (PBA) of Arthur Fleck in the Joker movie. The Joker movie is about a comedian named Arthur Fleck who has pseudobulbar affect (PBA). It's a neurological disorder that causes patients to lose emotional control temporarily. Arthur Fleck had various problems that made him a villain named Joker. This research used Roland Barthes'semiotic analysis technique, which focused on the meaning of denotation, connotation, and myth. The data source used in this research was a video recording of the Joker movie, then proceeding with selecting several scenes related to pseudobulbar affect. The data obtained were then analyzed using Roland Barthes'semiotics to determine the meanings in the scenes. This research's results are the meaning of denotation in this movie is the journey of a comedian named Arthur Fleck who suffered from the disease pseudobulbar affect (PBA) with various problems that make him become a villain named Joker. The meaning of the connotation is Arthur Fleck's laugh, which he cannot control, which is interpreted by those around him as ridicule, annoyance, and threats. The myth is the negative public stigma against people with mental disorders, making it difficult for people with mental illnesses to interact socially, be shunned, and ridiculed.
\end{abstract}

Keywords: Semiotics; Roland Barthes; pseudobulbar affect; movie; Joker

Korespondensi: Muhammad Alif Agisa, S.I.Kom. Universitas Singaperbangsa Karawang. Jl. HS. Ronggo Waluyo, Puseurjaya, Kec. Telukjambe Timur, Kabupaten Karawang, Jawa Barat 41361. Email: alifagisa@ gmail.com 


\section{PENDAHULUAN}

Pseudobulbar affect (PBA) adalah gangguan neurologis (sistem saraf) yang ditandai dengan tertawa dan/atau menangis yang tidak disengaja, yang biasanya tidak proporsional atau tidak sesuai dengan keadaan emosi yang mendasarinya. Pseudobulbar affect (PBA) dapat menyebabkan stres berat, malu, dan cacat sosial bagi penderitanya. Studi pada populasi dengan stroke, atau kelainan gerakan lainnya menunjukkan bahwa pasien dengan pseudobulbar affect (PBA) atau gejala yang mirip dengan tertawa dan/atau menangis memiliki insiden depresi yang lebih besar, kesehatan mental yang terganggu dan penururnan kemampuan untuk melakukan aktivitas hidup sehari-hari (Colamonico, Formella, \& Bradley, 2012).

\section{Pseudobulbar affect (PBA) menurut Rosen} adalah kelainan regulasi ekspresi emosional, yang disebabkan oleh penyakit neurologis atau cedera yang mempengaruhi saraf otak. Pseudobulbar affect (PBA) ditandai dengan reaksi yang tiba-tiba, tangisan yang tidak terkendali, tertawa, atau bahkan keduanya. Reaksi yang ditimbulkan tergolong berlebihan, tidak konsisten dengan atau tidak proporsional dengan keadaan atau suasana hati yang mendasari penderita pseudobulbar affect (PBA) pada saat itu (Rosen \& Cummings, 2007).
Tawa merupakan ekspresi rasa senang, geli, gembira, dan sejenisnya dengan mengeluarkan suara (pelan, sedang, keras) (Kemendikbud RI, 2016). Tertawa adalah pencermin dari sebuah emosi manusia, yang dimana merupakan spektrum emosi yang mencakup kegembiraan, kekagetan, ketakutan, cinta kasih, kesedihan, kebencian, serta kemarahan. Tertawa berasal dari kata dasar tawa. Tertawa termasuk ke dalam kelas verba/kata kerja, maka tertawa itu pengalaman, keberadaan, suatu tindakan, atau pengertian dinamis lainnya (Muhyidin, 2008).

Pada tahun 1969, Poeck menjelaskan kriteria tentang pseudobulbar affect (PBA), dan kriteria tersebut adalah reaksi emosi yang tidak sesuai dengan situasi, tidak ada hubungan erat antara ekspresi emosional dan suasana hati pasien pada saat reaksi muncul, sulit bagi pasien untuk mengontrol tingkat dan durasi dari reaksi emosi yang muncul, tidak ada perubahan suasana hati yang sesuai dengan reaksi, yang mungkin konsisten atau tidak konsisten dengan suasana hati, tidak ada perasaan lega karena reaksi emosi yang telah diungkapkan (Crumpacker \& Engelman, 2014).

Pseudobulbar affect (PBA) merupakan satu contoh gangguan jiwa dari sekian banyaknya gangguan jiwa. Pada masa era globalisasi yang serba cepat seperti saat ini, tentunya ada saja tuntutan dan masalah hidup yang muncul setiap harinya yang dapat menjadi pemicu gangguan 
jiwa pada manusia. Gangguan jiwa dapat ditemui pada berbagai kelas sosial, baik pada kelas ekonomi atas, menengah, ataupun bawah. Gangguan jiwa merupakan gangguan satu, atau lebih fungsi jiwa, dan bisa dikategorikan menjadi dua jenis, yaitu adalah gangguan jiwa berat (psikosis), dan gangguan jiwa ringan (neurosa) (Sovitriana, 2019).

Gangguan jiwa menurut merupakan sebuah perubahan pada fungsi jiwa, yang menyebabkan gangguan pada fungsi jiwa, yang dimana akan menyebabkan penderitaan bagi seseorang dan hambatan dalam menjalankan bersosialisasi. Gangguan jiwa terdapat bermacam-macam yang menyebabkan penderita diperlakukan berbeda, seperti diskriminasi, diisolasi, atau bahkan hingga dipasung. Perlakuan-perlakuan tersebut sebenarnya tidak akan membantu penderita sama sekali, dan bahkan dapat menjadi lebih parah (Lubis, Krisnani, \& Fedryansyah, 2014).

Data Riset Kesehatan Dasar (Riskesdas) 2018, menyatakan rata-rata keluarga dengan anggota yang mengidap psikosis sebesar 7 dari 1000. Sedangkan, rata-rata gangguan mental emosional pada remaja sebesar 9,8\%. Data ini terus bertambah jika dibandingkan tahun 2013, yaitu sebesar 6\% (Abdi, 2019).

Masalah gangguan jiwa yang menyebabkan menurunnya kesehatan mental ini ternyata terjadi hampir di seluruh negara di dunia. WHO (World Health Organization) yaitu suatu badan dunia PBB yang menangani masalah kesehatan dunia, memandang serius masalah kesehatan mental dengan menjadikan isu global WHO. WHO mengangkat beberapa jenis gangguan jiwa seperti Schizoprenia, Alzheimer, epilepsi, keterbelakangan mental dan ketergantungan alkohol sebagai isu yang perlu mendapatkan perhatian lebih serius lagi (Lubis et al., 2014).

Penderita gangguan jiwa dan keterbelakangan mental sangatlah berbeda. Gangguan jiwa disebabkan karena banyak hal salah satunya yang banyak terjadi di Indonesia karena pengalaman kehidupan yang di alami penderita sehingga mengganggu pikiran serta jiwa mereka, sedangkan pada penyandang keterbelakangan mental disebabkan karena rendahnya IQ yang membuat sikap dan perilaku mereka berbeda dengan manusia normal lainnya. Penderita gangguan jiwa dan keterbelakangan mental adalah warga negara Indonesia dan memiliki hak-hak sama seperti warga negara Indonesia (Lubis et al., 2014).

Kurangnya kesadaran dan pengetahuan masyarakat Indonesia tentang penyakit atau kelainan mental, seringkali menimbulkan perlakuan yang salah terhadap penderita penyakit mental. Seperti contohnya terdapat fenomena dimana keluarga di daerah pelosok Indonesia lebih memilih memasung anggota keluarganya yang mengidap penyakit mental seperti Skizofrenia ketimbang membawanya 
ke rumah sakit. Belum lagi penderita penyakit mental yang diolok-olok dan dijauhi lingkungannya karena dianggap menyusahkan (Choresyo, Nulhaqim, \& Wibowo, 2015).

Fenomena gangguan jiwa juga telah banyak difilmkan. Menurut Undang-Undang Nomor 33 Tahun 2009 pada Bab 1 Pasal 1 tentang Perfilman, definisi film merupakan sebuah karya seni budaya dan media komunikasi massa yang dapat dibuat menggunakan kaidah sinematografi dengan/tanpa suara, serta dapat dipertontonkan (Vera, 2014).

Tan dan Wright mengatakan, film dapat disebut sebagai media komunikasi massa karena film menggunakan media untuk menjembatani komunikator dengan komunikan secara luas, atau berarti berjumlah banyak, tersebar di berbagai tempat, massanya bermacam-macam serta anonim, serta menciptakan suatu efek (Ardianto, Komala, \& Karlinah, 2014).

Film memiliki kekuatan dan kemampuan untuk merangkul berbagai segmen sosial, hal ini menyebabkan para ahli mengatakan bahwa film dapat memperngaruhi khalayak luas. Oleh karena itu, lahirlah berbagai penelitian yang berfokus pada dampak atau efek film terhadap khalayak. Dapat dilihat bahwa terdapat banyak penelitian mengenai film yang berhubungan dengan banyak macam topik (Sobur, 2003).

Menurut Devito, komunikasi massa merupakan sebuah proses dari pengiriman pesan kepada banyak orang atau massa. Komunikasi massa menggunakan saluran atau media untuk menyampaikan pesan, media yang digunakan adalah media cetak ataupun media elektronik (Nurudin, 2007).

Media yang digunakan untuk menjalankan komunikasi massa disebut dengan media massa. Media sangat vital bagi keberhasilan proses komunikasi. Media ialah sarana yang dipakai untuk mengirim pesan dari komunikator kepada komunikan yang berupa orang banyak (Nida, 2014).

Film tentu memiliki makna-makna serta pesan yang akan disampaikan. Daniel Chandler mengatakan bahwa, semiotika merupakan ilmu mengenai tanda. Semiotika didefinisikan sebagai ilmu tentang bagaimana masyarakat memproduksi makna, serta nilai-nilai pada sebuah sistem komunikasi. Menurut Paul Colbey, semiotika berasal dari bahasa Yunani, yaitu Seme, berarti penafsiran tanda (Rusmana, 2005).

Secara sederhana, representasi dapat diartikan sebagai gambaran mengenai suatu hal yang terdapat dalam kehidupan yang digambarkan kembali melalui suatu media. Chris Baarker mengatakan bahwa representasi sebagai sebuah konstruksi sosial yang mengharuskan manusia untuk mengeksplorasi pembentukan dari makna tekstual dan menghendaki penyelidikan tentang cara dihasilkannya makna 
pada beragam konteks. Representasi dan makna budaya memiliki materialitas tertentu (Vera, 2014).

Bila Saussure berfokus kepada makna denotatif, Roland Barthes mengembangkan semiologi Saussure, dengan menambahkan sistem penanda pada tataran konotatif. Roland Barthes juga menambahkan aspek lainnya, yaitu adalah mitos yang menandai suatu khalayak/ masyarakat (Vera, 2014). Semiotika Roland Barthes lebih berfokus kepada signifikasi dua tahap (Sobur, 2015).

Denotasi adalah tataran pertama yang maknanya tertutup, pasti, langsung, dan juga eksplisit. Denotasi disebut juga makna yang sebenarnya, yang telah disetujui bersama secara sosial, yang mengacu pada realita. Tanda konotatif adalah tanda dimana penandanya memiliki keterbukaan, atau makna yang tidak langsung, tidak pasti, serta implisit, yang menimbulkan terbukanya kemungkinan terhadap makna atau penafsiran baru. Menurut semiologi Roland Barthes, signifikansi tingkat satu disebut denotasi, sedangkan signifikansi tingkat dua disebut konotasi (Vera, 2014).

Roland Barthes menghubungkan konotasi dengan ideologi, yang ia sebut dengan 'mitos' yang digunakan untuk mengungkapkan dan memberikan pengesahan bagi nilai-nilai dominan yang berlaku. Mitos terdiri dari sebuah rantai makna yang sebelumnya sudah

\begin{tabular}{|c|c|c|}
\hline $\begin{array}{c}\text { Signifier } \\
\text { (pendanda) }\end{array}$ & $\begin{array}{c}\text { Signified } \\
\text { (petanda) }\end{array}$ & \\
\hline $\begin{array}{c}\text { Denotative sign } \\
\text { (tanda denotatif) }\end{array}$ & \\
\hline \multicolumn{2}{|c|}{$\begin{array}{c}\text { Conotative signifier } \\
\text { (tanda konotatif) }\end{array}$} & $\begin{array}{c}\text { Conotative } \\
\text { signified } \\
\text { (petanda } \\
\text { konotatif) }\end{array}$ \\
\hline \multicolumn{2}{|c|}{ Conotative sign } \\
(tanda konotatif)
\end{tabular}

Sumber: Sobur, 2013

Gambar 1 Peta Semiotika Roland Barthes

ada. Roland Barthes mengatakan bahwa mitos adalah perkembangan dari konotasi. Konotasi yang terbentuk lama di masyarakat adalah mitos (Vera, 2014)

Film Joker (2019) adalah film yang bergenre crime, drama thriller, yang mengangkat isu gangguan jiwa yang menuai banyak perdebatan pada saat penayangannya. Film yang mengisahkan awal perjalanan musuh bebuyutan Batman, Joker rilis pada tanggal 4 Oktober 2019. Film Joker berfokus pada seorang komedian yang gagal bernama Arthur Fleck (diperankan oleh Joaquin Phoenix) yang juga menderita pseudobulbar affect (PBA).

Di dalam film Joker, banyak menampilkan adegan-adegan tokoh Arthur Fleck yang selalu tertawa walaupun nasib buruk selalu menimpanya. Arthur selalu dikhianati, dibohongi, serta ditolak oleh lingkungannya. Namun, di tengah-tengah segala kondisi Arthur yang penuh kesedihan dan penolakan, Arthur 
selalu tertawa karena penyakit Pesudobulbar Affect yang dideritanya. Berdasarkan latar belakang tersebut, maka tujuan dari penelitian ini untuk mengetahui makna-makna dari pseudobulbar affect (PBA) dari tokoh Arthur Fleck pada film Joker.

\section{METODE PENELITIAN}

Pendekatan yang peneliti pakai dalam penelitian ini merupakan pendekatan kualitatif. Bogdan dan Taylor berpendapat, penelitian kualitatif ialah suatu langkah penelitian yang menghasilkan data yang bersifat deskriptif berbentuk ucapan atau tulisan dari perilaku objek yang diteliti (Seto, 2018).

Penelitian ini menggunakan Paradigma Konstruktivisme karena berusaha melihat komunikasi sebagai produksi pertukaran arti. Tujuan dari penelitian konstruktivisme yaitu untuk menginterpretasikan dan merekonstruksi berbagai konstruksi yang sudah ada sebelumnya dan mempunyai keterbukaan interpretasi baru sejalan dengan berkembangnya waktu. Penelitian ini bersifat deskriptif karena data yang diteliti berupa kata-kata, gambar, dan dialog (Seto, 2018).

Objek penelitian ini adalah film Joker karya dari sutradara Todd Philips berupa visual dan potongan gambar, serta dialog pada film Joker yang berhubungan dengan pseudobulbar affect (PBA), dengan fokus kepada karakter

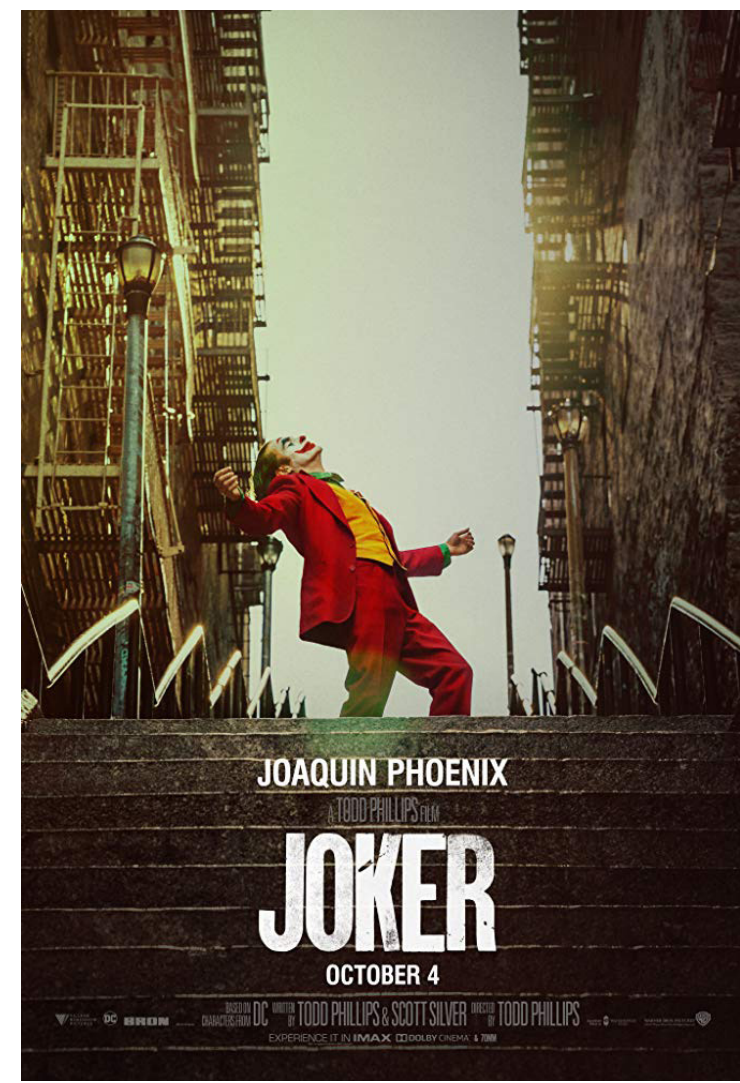

Sumber: IMDB, 2019

\section{Gambar 2 Poster Film Joker}

utama yang bernama Arthur Fleck. Arthur Fleck adalah seorang badut pesta dan komedian yang tinggal bersama ibunya, Penny, di Gotham City. Gotham City penuh dengan kejahatan dan pengangguran, serta kemiskinan. Arthur menderita kelainan medis yang menyebabkan dia selalu tertawa pada waktu yang tidak tepat. Arthur selalu mengalami penolakan dan pengkhianatan dalam hidupnya. Arthur difitnah oleh rekan kerjanya, dipecat dari pekerjaannya, tidak sengaja membunuh 3 orang di dalam kereta bawah tanah, lalu Arthur menemukan bahwa selama ini ibunya telah membohongi Arthur, hingga akhirnya Arthur membunuh ibunya sendiri. Kekacauan terjadi di kota Gotham, dan 
membuat Arthur menjadi Joker.

Data primer pada penelitian ini adalah rekaman video film Joker, terutama pada scene atau adegan dimana Arthur sedang tertawa dan menunjukan bahwa ia mengidap penyakit pseudobulbar affect (PBA). Data sekundernya adalah data yang sudah ada sebelumnya dan tersedia dalam bentuk publikasi serta informasi yang diterbitkan berbagai organisasi atau perusahaan, termasuk buku dan jurnal.

Teknik pengumpulan data yang digunakan adalah dokumentasi dan studi pustaka (Kriyantono, 2006). Peneliti akan mendokumentasikan scene atau adegan dalam film Joker yang merepresentasikan pseudobulbar affect (PBA) pada tokoh Arthur Fleck. Studi Pustaka, dilakukan dengan membaca artikel atau literatur sebagai dasar dan panduan bagi peneliti dalam melakukan penelitian ini.

Studi mengenai pseudobulbar affect (PBA) itu sendiri, sudah mulai banyak dilakukan, terutama di negara-negara maju. Dalam beberapa tahun ini, penelitian-penelitian mengenai gejala-gejala pseudobulbar affect (PBA), penyebab, serta efek yang dialami penderita dan bagaimana mengatasinya, sudah mulai banyak dilakukan, seperti misalnya penelitian oleh Aiesha Ahmed pada tahun 2013, yang meneliti tentang bagaimana seseorang dapat hidup dengan pseudobulbar affect (PBA), yang tentunya menjadi beban bagi kehidupan sosial dan emosional penderitanya (Ahmed \& Simmons, 2013)

Penelitian-penelitian sejenis seperti ini akan peneliti gunakan dalam membandingkan tanda-tanda yang memperlihatkan kehidupan penderita pseudobulbar affect (PBA) dalam film Joker, dan ideologi mengenai pseudobulbar affect (PBA) ataupun gangguan kejiwaan itu sendiri yang berkembang di masyarakat.

Teknik analisis yang digunakan adalah analisis semiotika Roland Barthes. Barthes mengembangkan semiotika dalam beberapa tahap yaitu denotasi dan konotasi yang di dalamnya terkadung pula makna mitos. Semiotik Roland Barthes menghasilkan makna secara objektif untuk memahami makna secara tersirat dalam film Joker yang menjadi objek penelitian ini. Peneliti memilih teknik ini karena dapat membantu peneliti dalam menganalisa tandatanda audio maupun visual dalam film Joker, yang akan menghasilkan makna denotatif dan konotatif, yang akan menunjukkan mitos yang berkembang di masyarakat mengenai penderita pseudobulbar affect (PBA).

Semiotika Roland Barthes juga telah sering digunakan dalam berbagai penelitian mengenai makna-makna yang disampaikan pada film, yang akhirnya menunjukkan mitos dan ideologi yang terdapat dalam masyarakat. Seperti misalnya, penelitian mengenai gender pada film 
Brave, yang menghasilkan bahwa gender dalam film Brave memiliki makna denotasi perempuan dituntut untuk terlihat dan berperilaku sempurna oleh lingkungannya, makna konotasinya adalah penolakan terhadap perjodohan yang dilakukan sang wanita, sebagai bentuk pemberontakan terhadap tradisi dan budaya lingkungan, dan mitosnya adalah bahwa akan adanya bencana yang terjadi, apabila ada seseorang yang melanggar tradisi budaya atau kebiasaan adat (Sutorini, Alif, \& Sarwani, 2019).

\section{HASIL DAN PEMBAHASAN}

Adegan 1 - Sesi Konsultasi Arthur Fleck. Adegan saat Arthur Fleck berkonsultasi mengenai penyakitnya kepada psikiater yang bernama Debra Kane. Mereka membahas tentang perkembangan penyakit dari Arthur Fleck.

Makna denotasi pada adegan ini terlihat Arthur Fleck tiba-tiba tertawa, kemudian batuk sembari memegangi lehernya. Arthur

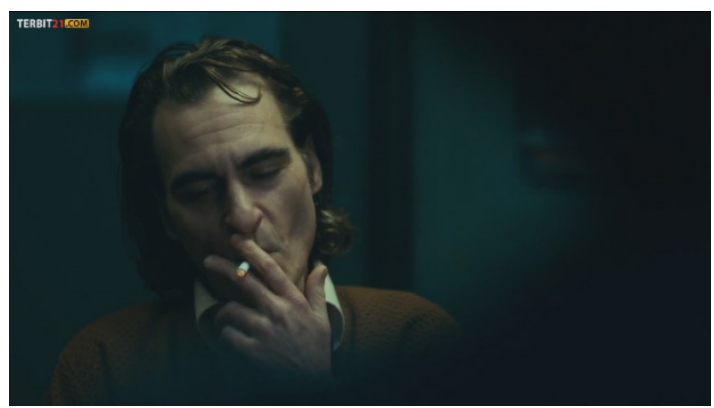

Sumber: Film Joker, 2019

Gambar 3 Arthur Fleck Menghisap Rokok menghisap sebatang rokok, lalu Debra Kane meminta untuk melihat buku harian Arthur Fleck. Arthur menggoyang-goyangkan kakinya. Arthur bercerita bahwa ia sedang mengejar karir sebagai pelawak tunggal, lalu memberikan buku hariannya kepada Debra Kane. Debra Kane membuka buku harian Arthur, lalu membaca kalimat, "Aku harap kematianku menghasilkan lebih banyak uang daripada hidupku". Arthur membenturkan kepalanya ke pintu ruang pengamatan. Arthur meminta untuk menambahkan obatnya, namun Debra menolak karena Arthur sedang memakai 7 jenis obat berbeda. Arthur berkata bahwa ia tidak ingin merasa buruk lagi.

Makna konotasi yang terdapat dalam adegan ini adalah tertawa Arthur yang dimulai dengan suara seperti sedikit tercekik dari belakang tenggorokan, lalu dilanjutkan dengan tawa terbahak-bahak. Menurut Judi James, ini merupakan jenis tawa yang tergolong natural, ekspresif dan dapat menular kepada orang di sekitarnya. Seseorang dengan gaya tawa tersebut biasanya menyenangkan, mudah untuk bersosialisasi serta rendah hati (Wolipop, 2013).

Selanjutnya Arthur Fleck menghisap sebatang rokok. Arthur pada film Joker digambarkan sebagai seorang pecandu rokok, hal ini dibuktikan dengan banyaknya adegan Arthur merokok di sepanjang film.

Seseorang dapat menjadi perokok 
disebabkan karena besarnya skor aspek neuroticisme. Neurotisme adalah kepribadian yang dicirikan dengan perasaan mudah mengalami emosi-emosi negatif seperti takut, cemas, mudah marah, depresi, serta perasaan tidak nyaman yang berdampak pada ketidakmampuan menyesuaikan diri. Menurut Anggriana, individu dengan tipe ini menunjukkan perilaku yang menunjukkan ketidakstabilan emosi (Putra \& Suhadianto, 2017).

Merokok dipilih dengan alasan sebagai cara untuk mengatasi ketegangan, cemas, depresi dan ketakutan, karena dengan merokok dianggap dapat membuat perasaan seseorang menjadi tenang dan senang. Penelitian Horn mengatakan bahwa $80 \%$ perokok menyatakan perasaan mereka lebih tenang, dan lebih senang setelah menghisap rokok (Putra \& Suhadianto, 2017).

Arthur menggoyang-goyangkan kakinya. Menurut Liza Marielly Djaprie M.Si,Psi,SC pada tahun 2015, individu yang terlihat menggerakkan kakinya saat duduk, bisa jadi itu adalah sebuah bentuk luapan emosi. Orang yang sedang stres pun ada yang menyalurkannya dengan menggerakkan anggota tubuhnya. Menggerakkan anggota tubuh seolah menjadi upaya untuk meredam stres (Agung, 2015).

Mitos pada Adegan 1. Arthur Fleck berkonsultasi setiap rutin dengan Debra
Kane, selaku psikiater. Arthur memberikan perkembangan mengenai penyakitnya kepada Debra, dan Debra memberikan obat dan saran kepada Arthur. Dapat dikatakan Arthur rutin berinteraksi dan berkomunikasi dengan Debra.

Banyak orang yang merasa tidak normal secara mental, seperti merasa stres, tertekan, takut atau cemas. Keadaan ini juga bisa dikatakan sebagai gejala awal dari suatu gangguan jiwa, namun hanya bila perasaan tersebut berada di luar batas, baru bisa dikatakan sebagai gangguan jiwa. Gangguan jiwa dapat mengganggu kehidupan sehari-hari dan menimbulkan banyak masalah dalam fungsi sosial, seperti ketidakmampuan untuk bekerja sama dengan orang lain atau menjalin hubungan dengan orang lain. Gejala dan penyakit mental ini dapat disembuhkan melalui konsultasi dan pengobatan oleh psikiater (Choresyo et al., 2015).

Kesadaran masyarakat Indonesia terhadap gangguan jiwa masih sangat rendah, karena fenomena ini sudah ada sejak lama, hingga saat ini masih banyak masyarakat yang tanpa disadari menderita gangguan jiwa, namun tidak ada orang di sekitar mereka yang paham mengenai gangguan jiwa itu sendiri. Anggota masyarakat yang memiliki kondisi seperti ini, seharusnya dirujuk ke orang yang ahli dalam pengobatan penyakit mental, seperti misalnya seorang psikiater ataupun ahli kejiwaan. Di 
sebagian besar masyarakat Indonesia, mitos tentang orang yang menderita penyakit jiwa, atau yang sering disebut sebagai "sakit jiwa" atau "gila" dalam kehidupan sehari-hari masih memprihatinkan. Akibat persepsi negatif tentang gangguan jiwa di masyarakat Indonesia, banyak keluarga yang merasa malu dan tidak ingin membawa keluarganya ke rumah sakit jiwa, sehingga penderita gangguan jiwa pada akhirnya tidak akan mendapat perawatan yang tepat, dan kondisinya bisa semakin memburuk (Choresyo et al., 2015).

Kurangnya kesadaran dan pengetahuan masyarakat tentang penyakit jiwa atau gangguan jiwa biasanya mengarah pada penganiayaan terhadap penderita penyakit jiwa. Misalnya, ada fenomena keluarga di daerah terpencil di Indonesia lebih memilih menahan anggota keluarga yang menderita penyakit jiwa seperti skizofrenia daripada mengirimnya ke rumah sakit. Belum lagi perlakuan yang diterima oleh orang-orang yang dianggap sakit jiwa, mereka diejek dan dijauhi oleh lingkungan sekitar karena dianggap merepotkan. Di masyarakat, ada banyak kepercayaan atau mitos yang salah tentang penyakit jiwa, disebabkan oleh gangguan setan, beberapa orang menyatakan bahwa itu adalah akibat dari ilmu sihir dan karena kutukan atau hukuman atas dosadosanya. Keyakinan yang salah seperti itu hanya akan merugikan pasien dan keluarganya, karena penderita gangguan jiwa tidak ditangani secara tepat waktu dan akurat (Choresyo et al., 2015).

Menurut Joyce Hoffman, yang telah mengidap pseudobulbar affect (PBA) sejak tahun 2011, berada di sekitar orang dan melakukan komunikasi dengan intensif, sebenarnya banyak membantu ia menjalani hari-hari dengan pseudobulbar affect (PBA). Dengan membiasakan berkomunikasi saat gejala muncul, akan membuat orang-orang di sekitar Joyce mengerti tentang pseudobulbar affect (PBA). Orang-orang mulai menghargai keberanian dan kejujuran Joyce yang tidak menutupi penyakit pseudobulbar affect (PBA) yang dideritanya ini (Aroshas, 2018).

Adegan 2 - Arthur Ditegur Di Dalam Bus. Adegan saat Arthur Fleck di dalam bus. Arthur mengajak bermain anak kecil yang duduk di depannya, namun Arthur diminta ibu sang anak untuk tidak mengganggunya.

Makna denotasi pada adegan 2 adalah Arthur Fleck sedang duduk di dalam bus dan

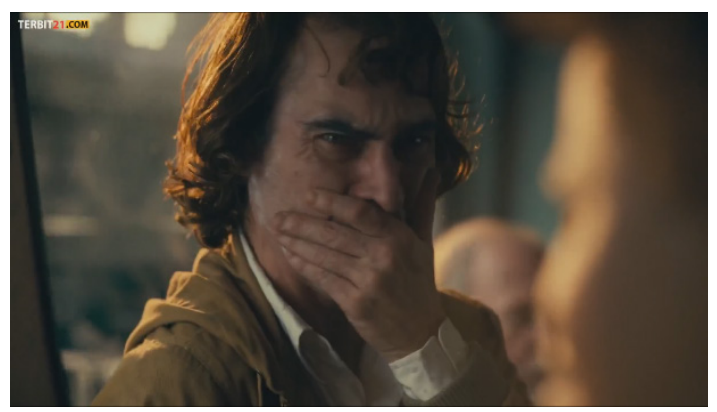

Sumber: Film Joker, 2019

Gambar 4 Arthur Fleck Menutup Mulutnya Saat Tertawa 
melihat ke luar jendela. Arthur kemudian mengajak bermain seorang anak kecil yang duduk tepat di depan Arthur. Anak kecil itu kemudian tertawa. Perempuan yang duduk di samping anak tersebut, yang adalah ibu dari anak tadi, kemudian menoleh ke belakang dan memberi tahu Arthur untuk tidak mengganggu anaknya. Arthur tiba-tiba tertawa dan kemudian menutup mulut dengan tangannya. Arthur mengeluarkan kartu yang bertuliskan, "Maafkan tawaku: Aku punya penyakit. Ini kondisi medis yang menyebabkan tertawa tak terkendali secara seketika, sering dan tidak sesuai dengan apa yang kau rasakan. Ini bisa menimpa orang dengan cedera otak atau kondisi neurologis tertentu".Arthur meminta maaf sembari tertawa. Makna Konotasi pada adegan 2 adalah Arthur tiba-tiba tertawa terbahak-bahak, lalu Arthur menutup mulutnya. Arthur terlihat ingin menghentikan tawanya karena merasa mengganggu orang-orang di sekitarnya, namun tidak bisa dan akhirnya ia menutup mulut dengan tangannya.

Menurut Judi James, suara tawa terdengar lepas, nyaring dan kasar, berpotensi untuk mengganggu orang di sekitarnya. Jenis tawa seperti ini biasanya terdengar dengan nada tinggi. Tawa semacam ini biasanya dilakukan oleh seseorang karena ingin didengar atau diapresiasi oleh orang lain (Wolipop, 2013). Gaya tertawa Arthur dan gerakkan menutup mulutnya berbanding terbalik, di sini Arthur tidak ingin didengar atau dikagumi. Arthur hanya ingin meminimalisir suara tawa yang ia buat dengan menutup mulutnya.

Ibu dari sang anak mengatakan, "Bisa kau berhenti mengganggu anakku?". Maksud "mengganggu" dalam kalimat tersebut adalah “mengajak bermain". Ibu sang anak tidak ingin anaknya bermain dengan Arthur, hal itu dianggap mengganggu oleh sang ibu, oleh karena itu ia menegur Arthur untuk tidak mengajak anaknya untuk bermain lagi.

Mitos pada adegan 2. Saat tertawa yang tidak terkendali, Arthur mengeluarkan kartu dan memberikannya kepada ibu sang anak. Kartu tersebut bertuliskan, "Maafkan tawaku: Aku punya penyakit. Ini kondisi medis yang menyebabkan tertawa tak terkendali secara seketika, sering dan tidak sesuai dengan apa yang kau rasakan. Ini bisa menimpa orang dengan cedera otak atau kondisi neurologis tertentu".

Stigma negatif terhadap para penderita gangguan jiwa akan mengarah pada penolakan, sehingga individu maupun masyarakat akan cenderung mengembangkan perasaan tidak suka. Disamping itu pula individu/masyarakat akan mengembangkan rasa tidak percaya ketika harus terlibat dalam aktivitas sosial ataupun dalam melakukan hubungan interaksi dengan yang ditolak tersebut. Penolakan ini bisa atau 
dapat memicu munculnya sikap agresif dan perilaku negatif terhadap orang dengan masalah kejiwaan tersebut. Ruang-ruang gerak orang dengan masalah kejiwaan sangat terbatas, ini terlihat dari sikap masyarakat/lingkungan sekitar yang terkesan "memusuhi" dengan cara melalukan penolakan dalam proses interaksi dengan penderita gangguan jiwa (Putro, 2018).

Sikap penolakan terhadap penderita gangguan jiwa juga terlihat dari adanya kecenderungan keluarga/masyarakat untuk menjadikan Rumah Sakit Jiwa sebagai tempat pembuangan bagi orang dengan gangguan jiwa. Setelah diantar, keluarga tidak pernah membesuk lagi, pasien dianggap sudah menjadi tanggungjawab petugas Rumah Sakit Jiwa, sedangkan keluarga tidak mau tahu tentang keadaan pasien. Konsekuensinya, ditemukan adanya pasien di Rumah Sakit Jiwa yang telah menjadi warga disana lebih dari lima sampai sepuluh tahun tanpa pernah diketahui dimana alamat dan siapa keluarganya. Keluarga bahkan masyarakat menilai Rumah Sakit Jiwa memiliki reputasi buruk di masyarakat. Stereotip sebagai tempat pembuangan, pengumpul, dan kurungan bagi pasien gangguan jiwa melekat padanya. Akibatnya label sakit dan status identitas pasien berpengaruh kuat dalam stigmatisasi di masyarakat (Putro, 2018).

Menurut Amy Elder, yang telah mengidap pseudobulbar affect (PBA) sejak tahun 2011, mengedukasi orang-orang di sekitarnya dapat membantu pemulihan pseudobulbar affect (PBA) yang dideritanya. PBA yang Amy idap mulai membaik seiring berjalannya waktu. Orang-orang di sekitar Amy perlu memahami bahwa reaksi pseudobulbar affect (PBA) muncul dengan tidak terkendali, dan akhirnya orang-orang di sekitar Amy mulai terbiasa dan memaklumi (Aroshas, 2018).

Adegan 3 - Stand Up Comedy Arthur Fleck. Adegan Arthur Fleck saat melakukan komedi tunggal atau stand up comedy. Arthur dipersilakan naik ke panggung oleh pembawa acara, dan Arthur memberikan lelucon-lelucon yang ada dalam buku catatannya.

Makna denotasi pada adegan 3 ini adalah terlihat seorang pembawa acara stand up comedy mempersilakan Arthur Fleck untuk naik ke atas panggung. Arthur naik ke atas panggung, tersenyum beberapa saat, kemudian tiba-tiba Arthur tertawa. Arthur tertawa secara terus-menerus hingga membelakangi penonton,

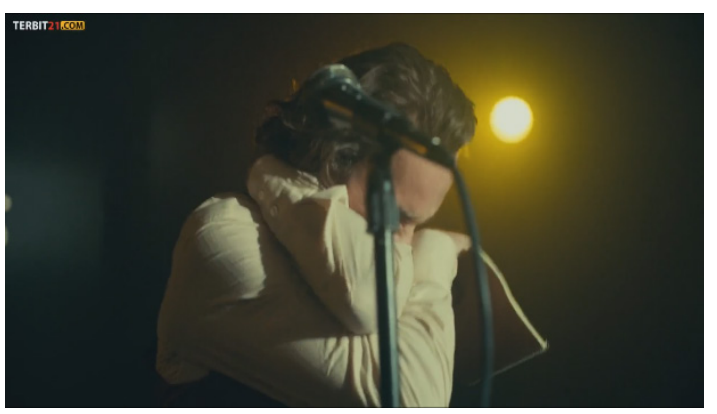

Sumber : Film Joker, 2019

Gambar 5 Arthur Menahan Tawa Di Atas Panggung 
kemudian Arthur menutup mulutnya dengan lengannya. Arthur membuka buku catatan yang ia bawa untuk melihat lelucon yang ia buat. Ia kemudian membacakan lelucon yang tertulis di buku tersebut. Arthur menutup penampilan stand up comedy-nya diiringi dengan tepuk tangan dari penonton.

Makna konotasi adegan 3. Arthur naik ke atas panggung dan tersenyum, Arthur terdiam cukup lama, dapat dikatakan kalau Arthur sedang gugup untuk melakukan stand up comedy di depan orang banyak. Gangguan kecemasan sosial adalah suatu bentuk rasa takut atau cemas terhadap interaksi atau situasi sosial dengan orang lain baik sebelum, sesudah, maupun selama berada dalam situasi tersebut. Individu dengan gangguan kecemasan sosial biasanya merasa takut untuk mengatakan, atau melakukan sesuatu di depan orang lain, karena mereka menganggap hal itu akan memalukan (Adrian, 2019).

Arthur Fleck tertawa terbahak-bahak. Menurut Judi James, suara tawa yang terdengar lepas, keras serta menggelegar dapat membuat orang di sekitarnya terganggu, karena gaya tertawa ini biasanya terdengar dengan nada yang tinggi. Gaya tertawa ini biasanya dilakukan oleh seseorang karena dirinya ingin didengar, atau dikagumi oleh orang lain (Wolipop, 2013)

Arthur membuka buku catatan yang ia bawa, untuk melihat lelucon yang ia buat.
Ini menandakan bahwa Arthur tidak siap untuk tampil stand up comedy, karena Arthur "mencontek" materi yang telah ia tulis, dan tidak mengapalkannya. Dengan mencontek materi di atas panggung, dapat dikatakan bahwa Arthur Fleck bukanlah professional stand up comedian, melainkan hanya amateur stand up comedian.

Arthur menutup penampilan stand up comedy dengan tepuk tangan dari para penonton. Tepuk tangan merupakan tamparan telapak tangan kanan dengan telapak tangan kiri sehingga menciptakan bunyi. Tepuk tangan berasal dari kata dasar tepuk (Lektur ID, 2020). Tepuk tangan menandakan bahwa penonton mengapresiasi dan menghargai usaha-usaha Arthur Fleck yang telah stand up comedy di atas panggung.

Mitos pada adegan 3. Setelah disambut oleh pembawa acara, Arthur Fleck naik ke atas panggung untuk stand up comedy. Di atas panggung, Arthur terdiam beberapa saat, dan kemudian tertawa hingga ia membelakangi penonton. Arthur kesulitan untuk melakukan stand up comedy.

Banyak anggapan yang beredar di tengah masyarakat bahwa ODGJ mengalami kejanggalan-kejanggalan yang terjadi pada mental dan emosinya seperti misalnya merasa stres, depresi takut, maupun gelisah, kondisi tersebut dapat juga dikatakan sebagai gejala 
awal dari gangguan mental, namun baru dapat dikatakan sebagai sebuah gangguan mental apabila perasaan-perasaan tersebut sudah melewatibatas kewajaran sehingga mengganggu keberfungsian sosial, seperti sulit untuk berkomunikasi atau dapat juga berpengaruh kepada menurunnya kondisi kesehatan secara jasmani. Gangguan mental dapat mengganggu kehidupan sehari-hari dan menimbulkan banyak masalah dalam keberfungsian sosial seperti tidak dapat bekerja sama dengan orang lain atau menjalin hubungan dengan orang lain (Choresyo et al., 2015).

Kebanyakan orang mudah saja dalam menentukan suatu perilaku sebagai tidak normal, khususnya jika perilaku itu sungguh sangat kentara keanehannya dibandingkan dengan perilaku biasa pada umumya. Penilaian itu semakin diperkuat lagi apabila suatu tindakan yang kelihatan aneh itu, tidak dimengerti maksud dia bertindak demikian. Akan tetapi, di lain pihak, gejala-gejala perilaku yang tidak kasat mata keanehannya tidak mudah untuk dinilai normal atau tidak normal (Gea, 2013).

Menurut Amy Elder, yang mengidap penyakit pseudobulbar affect (PBA) sejak tahun 2011, pseudobulbar affect (PBA) membuat Amy kesulitan untuk berkomunikasi dengan siapapun. Amy mengalami stroke pada usia 30 tahun, dan divonis mengidap pseudobulbar affect (PBA). Sejak saat itu, kehidupan Amy berubah. Amy kesulitan untuk menyampaikan apa yang ia maksud, dan ia rasakan kepada orang-orang yang berada di sekitarnya. Reaksireaksi pseudobulbar affect (PBA) yang muncul menghambat Amy untuk berkomunikasi (Elder A, 2018).

Adegan 4 - Pembunuhan Di Dalam Kereta. Adegan Arthur membunuh 3 orang pria di dalam kereta. Arthur diolok-olok dan dipukuli oleh 3 orang pria tersebut, lalu Arthur menembak dan mengejar mereka.

Makna denotasi pada adegan 4 adalah tiga orang pria sedang menggoda seorang wanita di dalam gerbong kereta. Arthur yang duduk tidak jauh dari mereka, tiba-tiba tertawa. Salah seorang pria bertanya kepada Arthur apa yang lucu. Wanita tersebut segera pergi ke gerbong lain, kemudian 3 pria tersebut mengolok-olok Arthur yang tidak berhenti tertawa. Salah seorang pria meninju wajah Arthur hingga Arthur tersungkur. Arthur tiba-tiba mengeluarkan pistol dan menembaki mereka. Salah seorang

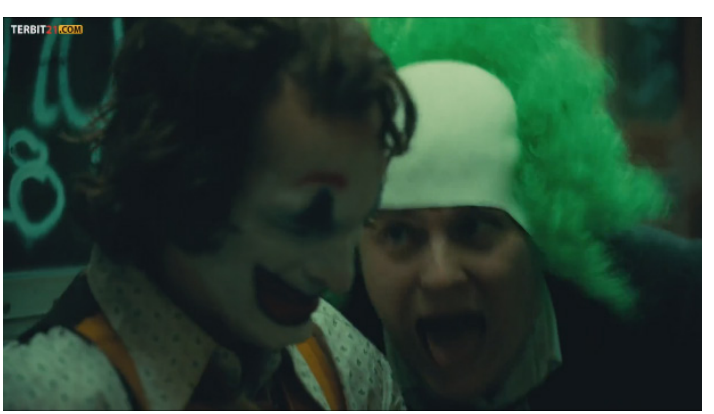

Sumber : Film Joker, 2019

Gambar 6 Arthur Diolok-olok Oleh Pria Di Dalam Kereta 
pria terkena luka tembak di bagian dada dan perut. Kereta berhenti, satu orang pria berlari ke luar dan meminta pertolongan. Arthur mengejar pria tersebut, lalu menembakinya berkali-kali.

Makna Konotasi pada adegan 4. Adegan 4, Arthur Fleck menggunakan make up seorang badut, lengkap dengan rambut palsu dan pakaian yang ia kenakan. Badut sering disewa sebagai penghibur dalam suatu acara. Di Italia, badut ialah penipu dan sudah dikenal sejak abad ke-16 dalam teater Commedia dell'arte. Badut dalam pertunjukan ini disebut Harlequin yang merupakan sosok pelayan amoral, lucu, serta gemar berbohong. Ditarik lebih jauh ke zaman Romawi kuno, ada mereka dengan sebutan Archimimus. Sosok badut ini bagian dari ritual pemakaman yang disewa guna menceritakan lelucon atau cemoohan. Para Archimimus juga punya kebebasan mengolok-ngolok golongan orang kaya, dan bahkan kekaisaran, tanpa harus takut dihukum mati (Bachtiar, 2017).

Setelah Arthur menembaki pria tersebut, Arthur diam sejenak dengan nafas yang terengah-engah. Nafas terengah-tengah yang Arthur alami dapat diartikan sebagai serangan panik. Serangan panik adalah munculnya rasa takut atau gelisah yang berlebihan dan terjadi secara tiba-tiba. Serangan panik ini bisa membuat penderitanya mengalami napas berat, cemas, dan rasa takut yang sulit mereda (Pane, 2019).
Mitos pada adegan 4. Saat Arthur Fleck tertawa tanpa sebab, ketiga pria di dalam kereta malah mengolok-olok dan memukuli Arthur. Ini disebabkan karena kesalahpahaman yang membuat situasi menjadi canggung. Ketidaktahuan ketiga pria tersebut mengenai penyakit seudobulbar affect (PBA) yang diderita Arthur membuat mereka salah paham, kemudian mengolok-olok dan memukuli Arthur.

Perilaku kekerasan adalah suatu keadaan dimana seseorang melakukan tindakan yang dapat membahayakan secara fisik baik terhadap diri sendiri, orang lain maupun lingkungan. Salah satu efek stigma ODGJ adalah perilaku kekerasan yang dilakukan oleh penderita terhadap orang lain termasuk keluarga, perawat dan masyarakat. Kekerasan yang dilakukan ODGJ biasanya dipicu oleh diri sendiri ataupun perlakuan lingkungan serta orang-orang sekitar yang dapat memicu amarah dari penderita yang tidak bisa mengontrol emosinya. ODGJ juga cenderung untuk melakukan kekerasan terhadap fasilitas umum atau barang-barang milik orang lain di masyarakat (Subu, Waluyo, Nurdin, Priscilla, \& Aprina, 2018).

Patrick Elder adalah suami dari Amy Elder yang mengidap pseudobulbar affect (PBA) sejak tahun 2011. Menurut Patrick, bagi mereka yang tidak tahu dan tidak terbiasa dengan penyakit pseudobulbar affect (PBA) ini, cara termudah 
untuk menjelaskannya adalah keinginan untuk tertawa dan menangis yang tidak terkendali, dan situasi ini dapat menyebabkan kesalahpahaman dan membuat situasi menjadi canggung. Orang yang tidak tahu tentang pseudobulbar affect (PBA) akan berpikir dan melakukan hal yang tidak pantas ketika reaksi pseudobulbar affect (PBA) dari seseorang muncul (Elder P, 2018).

\section{SIMPULAN}

Berdasarkan latar belakang, rumusan masalah, tujuan penelitian dan pembahasan yang telah diuraikan oleh peneliti menggunakan teori Semiotika Roland Barthes dalam pembahasan sebelumnya mengenai representasi pseudobulbar affect (PBA) tokoh Arthur Fleck dalam film Joker ini, dinilai bisa mencerminkan pseudobulbar affect (PBA) di kehidupan nyata melalui simbol-simbol dan pesan-pesan yang disampaikan melalui film ini, yang menggambarkan penderita pseudobulbar affect (PBA) sebagaimana faktanya. Hal ini dibuktikan dengan selalu terdapat makna denotasi, konotasi dan mitos pada setiap adegan yang peneliti bahas.

Makna denotasi yang terdapat pada film Joker adalah Arthur Fleck, seorang komedian yang menderita pseudobulbar affect (PBA), dimana ia tidak dapat mengontrol tawanya. Lingkungan, rekan kerja, hingga ibunya sendiri mulai mengecewakan Arthur, sehingga membuat Arthur menjadi seorang penjahat yang membuat kacau kota Gotham, bernama Joker.

Makna konotasi yang terdapat pada film Joker adalah tertawa Arthur Fleck yang tidak dapat ia kendalikan, diartikan oleh orangorang sekitarnya sebagai cemoohan, gangguan, hingga ancaman.

Makna mitos yang terdapat pada film Joker ini adalah pandangan masyarakat yang cenderung merendahkan ODGJ dan menganggap gangguan jiwa itu adalah aib yang harus ditutupi. Stigma masyarakat yang negatif membuat ODGJ kesulitan untuk berinteraksi secara sosial, dijauhi, dan diolok-olok.

Peneliti menyarankan kepada para pembaca, untuk memahami dan peduli tentang berbagai gangguan jiwa, maupun kepada orang-orang yang menderita gangguan jiwa. Dengan memahami dan peduli, kita jadi paham bagaimana kita bersikap terhadap orang dengan gangguan jiwa (ODGJ). Adanya film-film seperti Joker ini diharapkan dapat menjadi wadah edukasi tentang gangguan jiwa kepada para penontonnya. Para pengidap gangguan jiwa cenderung diperlakukan dengan berbeda. Kebanyakan menjadi korban bully di sekolah, keluarga, atau lingkungan sekitarnya. Perbedaan perlakuan dari lingkungannya membuat ODGJ menjadi kesulitan untuk menjalani hidup. Pseudobulbar Affect (PBA) tokoh Arthur Fleck 
dalam film Joker ini adalah salah satu contoh dari sekian banyak gangguan jiwa yang ada di masyarakat.

\section{DAFTAR PUSTAKA}

Abdi, A. P. (2019). Kemenkes Sebut Masalah Kesehatan Jiwa Perlu Disikapi Serius. Retrieved May 6, 2020, from Tirto.Id website: https://tirto.id/kemenkes-sebutmasalah-kesehatan-jiwa-perlu-disikapiserius-diuR

Adrian, K. (2019). Kenali Tiga Jenis Gangguan Kecemasan dan Gejalanya. Retrieved May 6, 2020, from Www.Alodokter.Com website: https://www.alodokter.com/ kenali-tiga-jenis-gangguan-kecemasandan-gejalanya

Agung, S. (2015). Membaca Makna di Balik Bahasa Tubuh Menggerak-gerakkan Kaki Saat Duduk. Retrieved May 6, 2020, from Detik Health website: https://health.detik. com/ulasan-khas/d-2996020/membacamakna-di-balik-bahasa-tubuh-menggerakgerakkan-kaki-saat-duduk/2/\#news

Ahmed, A., \& Simmons, Z. (2013). Pseudobulbar affect: Prevalence and management. Therapeutics and Clinical Risk Management, 9(1), 483-489.

Ardianto, E., Komala, L., \& Karlinah, S. (2014). Komunikasi Massa. Bandung: Simbiosa Rekatama Media.

Aroshas, T. (2018). It's Not What It Looks Like: My Life with Pseudobulbar Affect (PBA). Retrieved May 6, 2020, from Healthline website: https://www.healthline.com/ health/pba/portraits-of\#1

Bachtiar, A. (2017). Sejarah Kelam Badut, Sudah Horor Sejak Dulu. Retrieved May 6, 2020, from Kumparan website: https:// kumparan.com/absal-bachtiar/sejarahkelam-badut-memang-horor-sejak-dulu Choresyo, B., Nulhaqim, S. A., \& Wibowo, H. (2015). Kesadaran Masyarakat Terhadap Penyakit Mental. Prosiding Penelitian Dan Pengabdian Kepada Masyarakat, 2(3). https://doi.org/10.24198/jppm.v2i3.13587

Colamonico, J., Formella, A., \& Bradley, W. (2012). Pseudobulbar Affect: Burden of Illness in the USA. Advances in Therapy, 29(9), 775-798. https://doi.org/10.1007/ s12325-012-0043-7

Crumpacker, D. W., \& Engelman, W. A. (2014). Identifying Pseudobulbar Affect in Alzheimer's Disease and Dementia. US Neurology, 10(01), 10. https://doi. org/10.17925/usn.2014.10.01.10

Elder, A. (2018). 4 Ways PBA Has Affected My Life. Retrieved May 6, 2020, from https:// www.healthline.com/health/pba/amyelder\#1

Elder, P. (2018). To Others Caring for Someone with Pseudobulbar Affect (PBA): Have Empathy. Retrieved May 6, 2020, from https://www.healthline.com/health/pba/ caregiver-letter\#1

Gea, A. A. (2013). Psychological Disorder Perilaku Abnormal: Mitos dan Kenyataan. Humaniora, 4(1), 692. https://doi. org/10.21512/humaniora.v4i1.3479

IMDB. (2019). Joker. Retrieved from https:// www.imdb.com/title/tt7286456/

Kemendikbud RI, B. P. dan P. B. (2016). Hasil Pencarian - KBBI Daring. Badan Pengembangan Dan Pembinaan Bahasa, Kementerian Pendidikan Dan Kebudayaan Republik Indonesia. Retrieved from https:// kbbi.kemdikbud.go.id/entri/adil

Kriyantono, R. (2006). Teknik Praktis Riset Komunikasi.

Lektur ID. (2020). Tepuk Tangan Di Kamus 
Besar Bahasa Indonesia (KBBI). Retrieved May 30, 2020, from Lektur.ID website: https://lektur.id/arti-tepuk-tangan/

Lubis, N., Krisnani, H., \& Fedryansyah, M. (2014). Pemahaman Masyarakat Mengenai Gangguan Jiwa Dan Keterbelakangan Mental. Share : Social Work Journal, 4(2). https://doi.org/10.24198/share.v4i2.13073

Muhyidin, M. (2008). Merajut Kebahagiaan dan Kesuksesan dengan Air Mata Spiritual. Bandung: Mizan Pustaka.

Nida, F. L. K. (2014). Persuasi Dalam Media Komunikasi Massa. Jurnal Komunikasi Penyiaran Islam “AT-TABSYIR."

Nurudin. (2007). Pengantar Komunikasi Massa. Jakarta: Raja Grafindo Persada.

Pane, M. D. C. (2019). Ini Penyebab Napas Berat yang Sering Anda Rasakan. Retrieved May 6, 2020, from https://www.alodokter.com/ ini-penyebab-nafas-berat-yang-seringanda-rasakan

Putra, A., \& Suhadianto, S. (2017). Kecenderungan Kepribadian Neurotisme Dan Perilaku Merokok. Persona:Jurnal Psikologi Indonesia, 6(2), 111-120. https:// doi.org/10.30996/persona.v6i1.1300

Putro, B. D. (2018). Stigmatisasi Gangguan Jiwa. Bali: Universitas Udayana.

Rosen, \& Cummings. (2007). A Real Reason For Patients With Pseudobulbar Affect To Smile. Annals of Neurology, 61(2), 92-96 Rusmana, D. (2005). Tokoh dan Pemikiran Semiotika. Bandung: Tazkia Press.

Seto, I. W. (2018). Semiotika komunikasi: aplikasi praktis bagi penelitian dan skripsi komunikasi. Jakarta: Mitra Wacana Media. Sobur, A. (2003). Semiotika Komunikasi. Bandung: Remaja Rosdakarya.

Sobur, A. (2013). Semiotika Komunikasi. Bandung: PT Remaja Rosdakarya.

Sobur, A. (2015). Analisis Teks Media: Suatu Pengantar Untuk Analisis Wacana, Analisis Semiotika dan Analisis Framming. Bandung: PT Remaja Rosdakarya.

Sovitriana, R. (2019). Dinamika Psikologis Kasus Penderita Skizofrenia. Ponorogo: Uwais Inspirasi Indonesia.

Subu, M. A., Waluyo, I., Nurdin, A. E., Priscilla, V., \& Aprina, T. (2018). Stigma, Stigmatisasi, Perilaku Kekerasan dan Ketakutan diantara Orang dengan Gangguan Jiwa (ODGJ) di Indonesia: Penelitian Constructivist Grounded theory. Jurnal Kedokteran Brawijaya, 30(1), 53. https:// doi.org/10.21776/ub.jkb.2018.030.01.10

Sutorini, M. P., Alif, M., \& Sarwani, S. (2019). Semiotika Gender dalam Film Brave. ProTVF, 3(1), 101. https://doi. org/10.24198/ptvf.v3i1.21246

Vera, N. (2014). Semiotika Dalam Riset Komunikasi. In Bogor: Ghalia Indonesia (Vol. 8). Bogor: Ghalia Indonesia.

Wolipop. (2013). 8 Gaya Tertawa yang Bisa Dipakai untuk Menebak Isi Pikiran Orang. Retrieved May 6, 2020, from Wolipop website: https://wolipop.detik.com/love/ d-2241505/8-gaya-tertawa-yang-bisadipakai-untuk-menebak-isi-pikiran-orang 